\title{
Montmorillonite as the catalyst in oxidation of limonene with hydrogen peroxide and in isomerization of limonene
}

\author{
Mariusz Malko ${ }^{1^{*}}$, Adrian Krzysztof Antosik ${ }^{1}$, Agnieszka Wróblewska ${ }^{1^{*}}$, Zbigniew Czech ${ }^{1}$, \\ Katarzyna Wilpiszewska ${ }^{2}$, Piotr Miądlicki ${ }^{1}$, Beata Michalkiewicz ${ }^{3}$ \\ ${ }^{1}$ West Pomeranian University of Technology, Szczecin, Faculty of Chemical Technology and Engineering, Institute \\ of Organic Chemical Technology, Pułaskiego 10, 70-322 Szczecin, Poland \\ ${ }^{2}$ West Pomeranian University of Technology, Szczecin, Faculty of Chemical Technology and Engineering, Polymer Institute, \\ Pułaskiego 10, 70-322 Szczecin, Poland \\ ${ }^{3}$ West Pomeranian University of Technology, Szczecin, Faculty of Chemical Technology and Engineering, Institute \\ of Inorganic Technology and Environmental Engineering, Putaskiego 10, 70-322 Szczecin, Poland \\ "Corresponding authors: e-mail: agnieszka.wroblewska@zut.edu.pl, mariuszmalko@gmail.com
}

\begin{abstract}
In our studies montmorillonite (MMT) was used as the heterogeneous, natural catalyst. This material was previously prepared by bentonite purification with help of the sedimentation method. The obtained catalyst was characterized by: XRD, SEM, BET and EDX. Catalytic tests with montmorillonite as the catalyst were performed with the natural terpene $-\mathrm{R}-(+)$-limonene. This compound was oxidized with hydrogen peroxide and, moreover, in the separate process it was also isomerized. As the main products of limonene oxidation were detected: $(1,2-8,9)$-diepoxide, perillyl alcohol, carvone, carveol, 1,2-epoxylimonene and 1,2-epoxylimonene diol. In the isomerization of $\mathrm{R}-(+)$-limonene were formed: terpinenes, terpinolene and p-cymene. Conversions of limonene in these processes reached $70-80 \%$. The application of montmorillonite (the natural of origin) in the studied processes (oxidation and isomerization) is environmentally friendly, it allows to reduce the cost of the studied processes. The resulting products of the processes of oxidation and isomerization of $\mathrm{R}-(+)$-limonene have many applications.
\end{abstract}

Keywords: montmorillonite, R-(+)-limonene, oxidation, isomerization, hydrogen peroxide, heterogeneous catalysis.

\section{INTRODUCTION}

Montmorillonite (MMT) is a volcanic mineral with a density ranging between $1.9-2.7 \mathrm{~g} / \mathrm{cm}^{3}$. It is a clay material included in the bentonite rock discovered in the mid-19th century in Montmorillon, France. Also in Poland bentonite rocks are present. MMT is a basic constituent of bentonites (55-70\%), kaolinite (10-21\%), feldspar (10-16\%) and silica (1-2\%). The general chemical formula of MMT can be written as follows ${ }^{1-3}$ : $\mathrm{M}_{\mathrm{x}}\left(\mathrm{Al}_{4-\mathrm{x}} \mathrm{Mg}_{\mathrm{x}}\right) \mathrm{Si}_{8} \mathrm{O}_{20}(\mathrm{OH})_{4}$ where: $\mathrm{M}$ - cation of metal; $\mathrm{x}-0.5 \div 1.3$.

Montmorillonite is a layered aluminosilicate with a lamellar structure (lamellar is composed of three layers: two outer tetrahedral, comprising between them octahedral layer). The thickness of the MMT plate amounts to $0.96 \mathrm{~nm}$, the remaining dimensions are in the range of 200 to $1000 \mathrm{~nm}$, while the number of packages per unit of crystallographic cell varies from several to several thousand. It depends on external factors, among which we distinguish the type of layered mineral, the origin of its creation, the geological environment in which it was formed, and the mechanical forces acting on its particles. Between layers are located cations of metals, mainly sodium $\left(\mathrm{Na}^{+}\right)$or calcium $\left(\mathrm{Ca}^{2+}\right)$ and water molecules. Because of interstitial cations that have „loose” character, sodium montmorillonite (Na MMT) and calcium montmorillonite (Ca MMT) are distinguished. Figure 1 shows the layered structure of MMT.

Montmorillonite is a highly hydrophilic mineral used as nanofiller ${ }^{1-5}$. Due to the availability and low price, montmorillonite has been widely used in food, ceramic, rubber, paper, pharmaceutical, chemical and metallurgical industries. It is used as a thickener in emulsions, for the clarification of beverages, in production of mineral

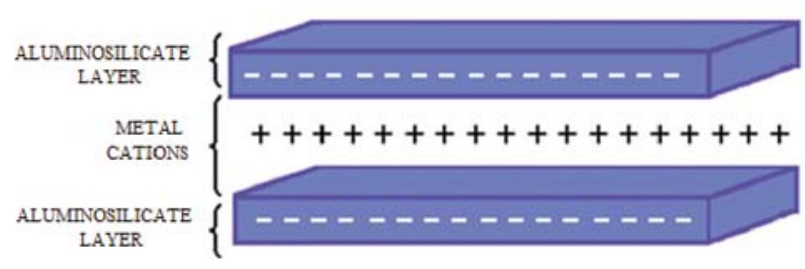

Figure 1. Layered structure of montmorillonite

fertilizers, drilling rigs, and for the reclamation of areas contaminated with heavy metals. Montmorillonites are used in various industries as catalysts or catalyst carriers. Raw bentonites can also serve as adsorbents, such as decolorizers, filtering systems, ion exchangers or they can be used as drilling fluids. In the form of a granular filter, montmorillonite is used for the purification and decolorization of drinking water, mineral and vegetable oils, as well as wines and other beverages ${ }^{4,6-8}$.

Montmorillonite clays were generally the most popular catalysts for pinenes isomerization process, although kaolinite clay was also successfully used for this purpose. Preliminary acid treatment of clays had a considerable effect on the conversion of pinenes. But the concentration of acid used ${ }^{9-11}$ and the temperature of acid treatment ${ }^{12}$, had a large impact on the ratio of the products received. The data about the dependence of the catalytic activity of acidic clays and isomerization selectivity on the nature of acid centers indicated that the transformations of pinenes to camphene occurred predominantly on the Bronsted acid centers ${ }^{13-14}$.

Application of montmorillonite clays as catalysts in terpenoids transformations leads to improved known process and often to reaction routes other than those that occurred in presence of traditional acid catalysts. This opens new prospects for the application of re- 
newable plant raw material in fine organic chemistry. Studies of the effects of the exchange cations on the isomerization of $\alpha$-pinene oxide showed that montmorillonite clays containing $\mathrm{Fe}^{3+}$ cations exhibited the highest activity $^{15}$. Isomerization of $\alpha$-pinene in the presence of acid-treated polycation exchanged montmorillonite clay leds to a considerably increase in yield of camphene in comparison with the yield of this compound in the presence of non-polycation-exchanged equivalents ${ }^{16}$. Investigation on of the applicability of montmorillonite clays containing organic cations like: tetramethylammonium, dodecyltrimethylammonium and octadecyltrimethylammonium cations as exchange cations in isomerization of $\alpha$-pinene revealed that only organoclays pretreated with acid possessed high catalytic activity ${ }^{17 .}$ Alumina pillared clays demonstrated a good activity and high selectivity with respect to camphene ${ }^{18}$. The selectivity over the best catalysts based on clays in isomerization of $\alpha$-pinene generally amounted to $40-65 \%$ with respect to camphene and $15-40 \%$ with respect to limonene, while conversion of $\alpha$-pinene was $70-90 \%$. Another interesting process, where montmorillonite clay K-10 was used, was process of isocembreol isomerization in allyl alcohol ${ }^{19}$. In this method were obtained tetradecahydrophenanthrenes with good yields. Process of $\alpha$-pinene isomerization to camphene ${ }^{20}$ was also performed over $\mathrm{Fe}$ - and $\mathrm{Cr}$-containing clinoptilolite catalysts. The exchange of natural zeolite clinoptilolite with $\mathrm{Fe}^{3+}$ and $\mathrm{Cr}^{3+}$ ions, changes the amount of surface acid sites without modifying the sample surface area, pore diameter and crystallinity. $\mathrm{Fe}^{3+}$ and $\mathrm{Cr}^{3+}$ loaded clinoptilolites exhibit higher Bronsted acidity in comparison to raw clinoptilolite and the catalytic activity strongly depends on the type and amount of supported element. Over the mesoporous clinoptilolite based catalysts, main products are camphene and limonene.

The process of verbeneol and verbeneol epoxide isomerization was studied with montmorillonite clay ${ }^{21}$. As catalysts were used acid treated montmorillonite and askanite-bentonite clay. This process demonstrated the possibility of complex intramolecular transformations of natural compounds in the presence of natural acidic clays with preservation of optical activity. Almost all these transformations can only occur on clay and do not proceed on traditional acid catalysts. Another process, where askanite-bentonite was used as the catalyst, was transformations of myrtenal epoxide ${ }^{22}$. This method showed good results in lower temperatures $\left(0-20^{\circ} \mathrm{C}\right)$ and it allowed to obtain: cumin aldehyde and cuminal, which are components of many essential oils, and they also exhibit biological activity.

Application of MMT and others natural materials for the catalytic reactions proved some fruitful approaches. These catalytic processes have many advantages such as no acid wastes, possibility of easy regeneration and recycling of heterogeneous catalyst. The transformations of terpenoids in the presence of clays are generally stereoselective processes.

$\mathrm{R}-(+)$-limonene (4-isopropenyl-1-methylcyclohexene) is colorless or yellow liquid with the molar mass of $136.23 \mathrm{~g} / \mathrm{mol}$ and with characteristic citrus scent. Limonene thanks to the presence of the chiral center on the fourth carbon atom in the cyclic ring occurs in nature in the form of two isomers (Fig. 2) or also in the form of racemic mixture.
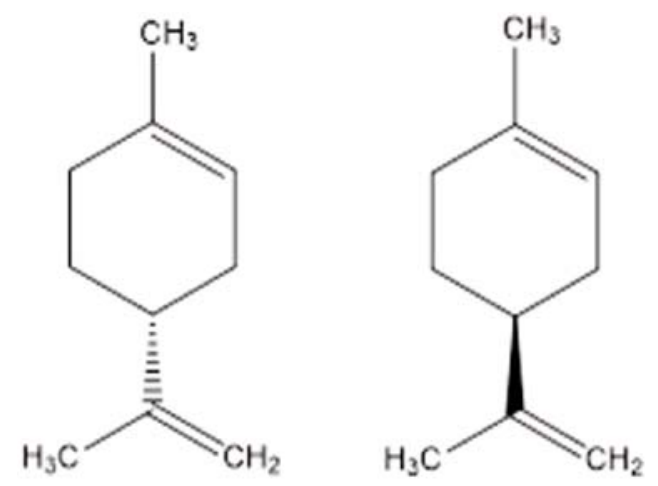

Figure 2. Enantiomers of limonene

$\mathrm{R}-(+)$-limonene occurs in citrus peels (sweet orange, tangerine, lemon and lime) and it is characterized by the following physical characteristics: boiling point $176^{\circ} \mathrm{C}$ (at $760 \mathrm{mmHg}$ ), melting point $-74^{\circ} \mathrm{C}$; density of $0.94 \mathrm{~g} / \mathrm{dm}^{3}$ and good solubility in methyl alcohol, ethanol, acetone and benzene. R-(+)-limonene in the Code of Federal Regulations is generally recognized as safe (GRAS) flavoring agent and can be found in common food items such as fruit juices, soft drinks, baked goods, ice creams, and puddings. On an industrial scale $\mathrm{R}-(+)$-limonene is produced in an amount of 73000 tons/year. The main source of this compound are orange peels, which are a waste from the industry producing fruit juices. The content of R-limonene in orange oils obtained from orange peels is very high and amounts to above $97 \%$. On the other hand, R-(+)-limonene has many applications as a base for synthesis of its oxygenated derivatives (1,2-epoxylimonene, carvone, carveol, and perillyl alcohol). R-(+)-limonene has been used in the epoxidation with hydrogen peroxide and t-butyl hydroperoxide over titanium-silicate catalysts ${ }^{23-25}$. Another application of this compound is catalytic asymmetric epoxidation of limonene using homogenic manganese Schiff-base complexes immobilized in ionic liquids ${ }^{26}$. Next very interesting oxidation process of $\mathrm{R}-(+)$-limonene is clean process of obtaining of derivatives of limonene starting from orange oil ${ }^{27}$. In this method as the catalyst palladium supported on copper-magnesium-aluminum hydrotalcite was used. This catalyst shared high catalytic activity in this process.

Figure 3 presents the ways the of $\mathrm{R}-(+)$-limonene transformation by 1) oxidation with hydrogen peroxide and by 2) isomerization. In those two processes, very important compounds having a lot of applications can be obtained.

Carvone and carveol are used as mosquito repellents. Moreover, they are used in food and flavor industries. $\mathrm{R}-(-)$-carvone is also used for air freshening products and, like many essential oils, oils containing carvones are used in aromatherapy and in alternative medicine ${ }^{28}$. Next product of oxidation of R-(+)-limonene is perillyl alcohol. This compound is very important because it may be used as an ingredient in cleaning products and cosmetics, and as a potential drug for treatment people with brain cancer ${ }^{29}$. Epoxidation products: 1,2-epoxylimonene and 8,9-epoxylimonene were used as monomers for synthesis of "smelling polymers"30-31. On the other 


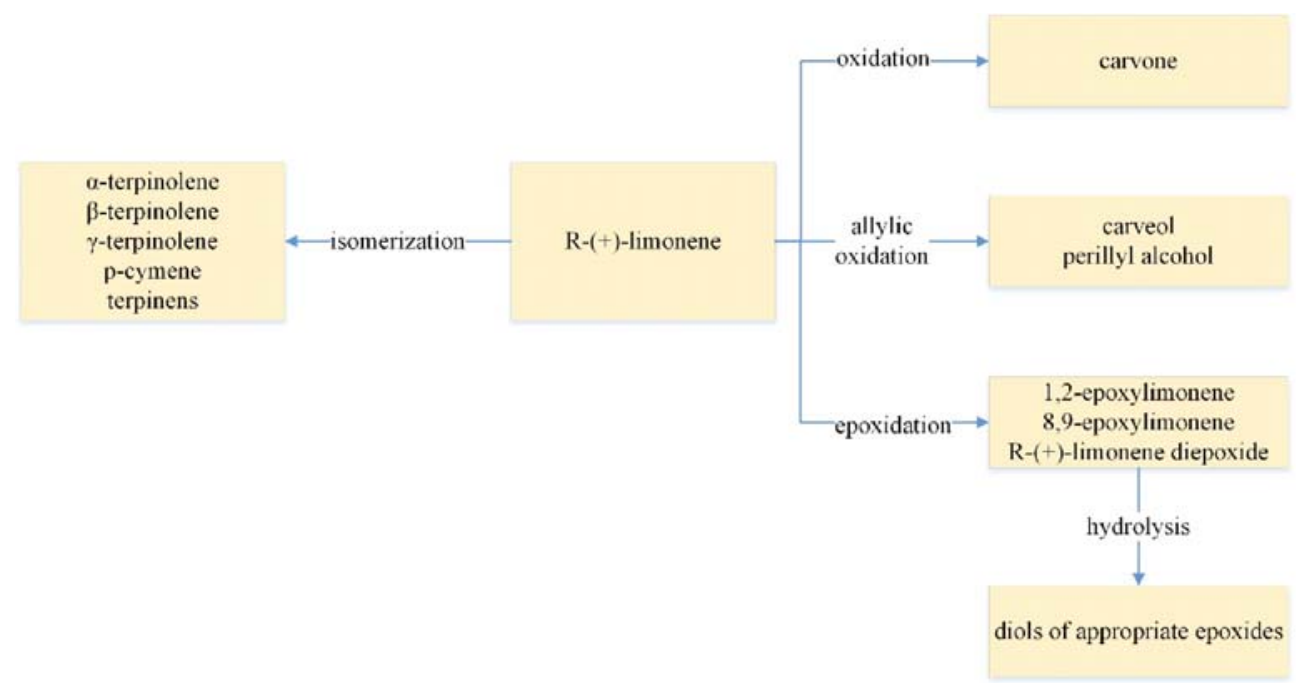

Figure 3. Oxidation and isomerization products obtained from R-(+)-limonene

hand, products of $\mathrm{R}-(+)$-limonene oxidation: carvone, carveol and perillyl alcohol were used as components of perfumes and flavoring agents used in the cosmetics and food industry.

The products of isomerization of $\mathrm{R}-(+)$-limonene have also important applications. Terpinenes are used as fragrant and flavoring agents in the cosmetic and food industry, and also in pharmaceutical and electronic industry. P-cymene is an important product and valuable intermediate in the chemical industry. Among other applications, p-cymene was used as a solvent for dyes and varnishes, as a heat transfer medium, as an additive in fragrances and musk perfumes, and for masking odor of industrial products ${ }^{32}$. However, the main use of $\mathrm{p}$-cymene is its transformation to p-cresol. Now, p-cresol is mainly produced via the alkylation of toluene with propylene, followed by oxidation and hydroperoxide cleavage ${ }^{32}$.

The aim of this work were the studies on the environmentally friendly process of the catalytic oxidation of $\mathrm{R}-(+)$-limonene with $\mathrm{H}_{2} \mathrm{O}_{2}$, and separately, on the isomerization of R-(+)-limonene. Sodium montmorillonite which was used as heterogeneous catalyst is cheap, and natural origin volcanic material. Limonene was received from biomass (orange peels) which are originated from production of juice fruits. The processes of $\mathrm{R}-(+)$-limonene oxidation and isomerization over montmorillonite are an example of new directions in organic technology. It is very important to establish the best conditions of conducing these two processes, considering applications products of $\mathrm{R}-(+)$-limonene oxidation and isomerization. This work presents the preliminary studies on R-(+)-limonene oxidation and isomerization processes. Such studies have not yet been presented in the literature.

\section{EXPERIMENTAL}

\section{Material}

The following raw materials were used for the studies: $\mathrm{R}-(+)$-limonene $(98 \%)$, water solution of hydrogen peroxide $(60 \mathrm{wt} \%, \mathrm{POCH})$, and sodium montmorillonite prepared from bentonite (technical grade, Zębiec S.A. Zębiec) according the method presented below.

\section{The preparation of the sodium montmorillonite}

To a beaker with the capacity of $2000 \mathrm{~cm}^{3}$ containing $900 \mathrm{~g}$ of distilled water $100 \mathrm{~g}$ of bentonite was added and obtained mixture was stirred for 30 minutes to give a homogeneous mixture. The $10 \%$ dispersion of bentonite in water was introduced into the centrifuge (Sigma $6 \mathrm{~K} 15$ ) and it was centrifuged for $10 \mathrm{~min}$ at $3000 \mathrm{rpm}$. The dispersion was then removed from the precipitate and dried until the water evaporated. Dry montmorillonite was then grinding. Figure 4 presents scheme of the purification of bentonite to montmorillonite catalyst.

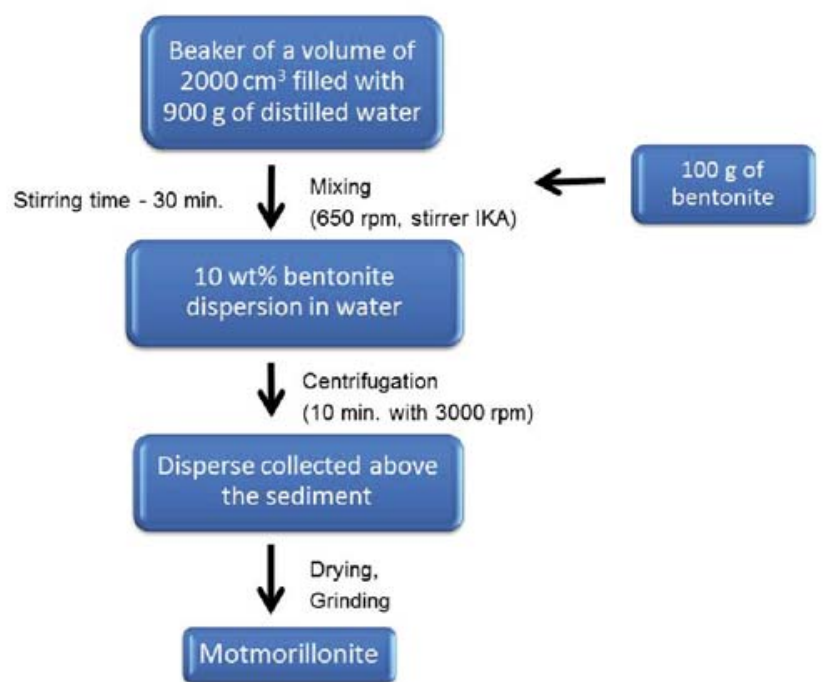

Figure 4. Scheme of the purification of bentonite to montmorillonite catalyst

\section{Characterization of montmorillonite}

The XRD scans were carried out on a PANalytical $\mathrm{X}$-ray Empyrean diffractometer using $\mathrm{Cu} \mathrm{K} \alpha$ radiation. The spectra were analyzed using X'Pert HighStore diffraction software.

The surface area, total pore volume and micropore volume were determined by nitrogen adsorption at 77 K. The measurements were performed via the Surface Area \& Pore Size Analyzer Quadrasorb evo provided by Quantachrome Instruments. Data were collected from a relative pressure $\left(\mathrm{p} / \mathrm{p}_{0}\right)$ range of 0.002 to 0.99 .

Scanning electron microscopy images were obtained using ultrahigh resolution field emission scanning electron 
microscope (UHR FE-SEM Hitachi SU8020). Energy dispersive X-rays (EDX) spectra were collected and analyzed on NSS 3.0 software. Samples for SEM/EDX analysis were attached on an aluminum sample holder using a double-stick electrically conductive carbon tape.

\section{Isolation of R-(+)-limonene}

$\mathrm{R}-(+)$-limonene, used for the processes of oxidation and isomerization, was obtained by the simply distillation. To the three-necked flask with the capacity of $500 \mathrm{~cm}^{3}$, equipped with a heating coil, a dropping funnel and a condenser were introduced previously cut orange peels. Then, water was added to the flask. The orange oil distillation was continued until the increase in the amount of the organic phase in the distillate was observed. In the last step, the obtained distillate was subjected to cold treatment to remove water from the product. The resulting product was examined by the coulombmetric Karl-Fisher method (water content) and also its purity was checked by the gas chromatography method.

\section{Catalytic tests}

Oxidation of R-(+)-limonene. The conditions of limonene epoxidation performing were as follows: temperatures $40,60,80$ and $100^{\circ} \mathrm{C}$, molar ratio of $\mathrm{R}-(+)$ limonene $/ \mathrm{H}_{2} \mathrm{O}_{2}=1: 1$, solvent (methanol) concentration $-80 \mathrm{wt} \%$, content of the montmorillonite (catalyst) $3 \mathrm{wt} \%$ and the intensity of stirring $500 \mathrm{rpm}$. The samples for the quantitative analyses were taken after the following reaction time: $0.5,1,23,24$ and $48 \mathrm{~h}$. The oxidation was performed in the glass reactor with the capacity of $25 \mathrm{~cm}^{3}$, equipped with the magnetic stirrer and the condenser. The post-reaction mixtures were analyzed by the gas chromatography and by iodometric method of analysis of the unreacted hydrogen peroxide. In the GC analyses the Focus apparatus equipped with the Restek RTX column $(0.53 \mathrm{~mm} \times 30 \mathrm{~m}$ x $1.0 \mathrm{um}$ film (polyethylene glycol $20.000 \mathrm{Da}$ )) was used. The carrier gas was helium, at a flow rate of $1 \mathrm{ml} / \mathrm{min}$. Column temperature was initially $60^{\circ} \mathrm{C}$ for $2 \mathrm{~min}$, then gradually increased to $240^{\circ} \mathrm{C}$ at $4^{\circ} \mathrm{C} / \mathrm{min}$. An external standard method was used to determine the composition of post-reaction mixtures. The qualitative analyses were performed by GC-MS method using a ThermoQuest apparatus equipped with a Voyager detector and a DB-5 column (filled with phenylmethylsiloxanes, $30 \mathrm{~m} \times 0.25 \mathrm{~mm} \times 0.5 \mathrm{um})$. The parameters of analyses were as follows: helium flow of 1 $\mathrm{ml} / \mathrm{min}$, the temperature of the sample chamber $200^{\circ} \mathrm{C}$, the temperature of detector $250^{\circ} \mathrm{C}$, the temperature of the furnace - isothermally for $2.5 \mathrm{~min}$ at the temperature of $50^{\circ} \mathrm{C}$, then increase with the speed of $10^{\circ} \mathrm{C} / \mathrm{min}$ to the temperature of $300^{\circ} \mathrm{C}$.

Isomerization of $\mathbf{R}-(+)$-limonene. The conditions of the limonene epoxidation performing were as follows: the temperatures $100,120,140,160$ and $180^{\circ} \mathrm{C}$, the content of the montmorillonite (catalyst) $15 \mathrm{wt} \%$ and the intensity of stirring $500 \mathrm{rpm}$. The samples for the quantitative analyses were taken after $5 \mathrm{~h}$ of reaction performing. The isomerization was performed in the glass reactor with the capacity of $25 \mathrm{~cm}^{3}$, equipped with the magnetic stirrer and the condenser. Quantitative analysis was done with a Thermo Electron FOCUS chromatograph equipped with an FID detector and a TR FAME column (filled with cyanopropylphenyl, $30 \mathrm{~m} \times 0.25 \mathrm{~mm} \times 0.25 \mathrm{um}$ ). The chromatographic parameters were as follows: helium flow $0.7 \mathrm{ml} / \mathrm{min}$, dispenser temperature $200^{\circ} \mathrm{C}$, detector temperature $200^{\circ} \mathrm{C}$, the temperature of the furnace - isothermally $7 \mathrm{~min}$ at $60^{\circ} \mathrm{C}$, then increase at $15^{\circ} \mathrm{C} /$ min to $240^{\circ} \mathrm{C}$. An external standard method was used to determine the composition of post-reaction mixtures. For products and unreacted substrate calibration curves were made of eight measurement points within a concentration range of $0-33 \mathrm{wt} \%$. The qualitative analyses were performed by GC-MS method using a ThermoQuest apparatus equipped with a Voyager detector and a DB-5 column (filled with phenylmethylsiloxanes, $30 \mathrm{~m}$ x $0.25 \mathrm{~mm} \times 0.5 \mathrm{um}$ ). The parameters of analyses were as follows: helium flow of $1 \mathrm{ml} / \mathrm{min}$, the temperature of the sample chamber $200^{\circ} \mathrm{C}$, the temperature of detector $250^{\circ} \mathrm{C}$ the temperature of the furnace - isothermally for $2.5 \mathrm{~min}$ at the temperature of $50^{\circ} \mathrm{C}$, then increase with the speed of $10^{\circ} \mathrm{C} / \mathrm{min}$ to the temperature of $300^{\circ} \mathrm{C}$.

\section{RESULTS AND DISCUSSION}

\section{Characteristic of montmorillonite catalyst}

EDX spectra of the MMT catalyst is presented in Figure 5.

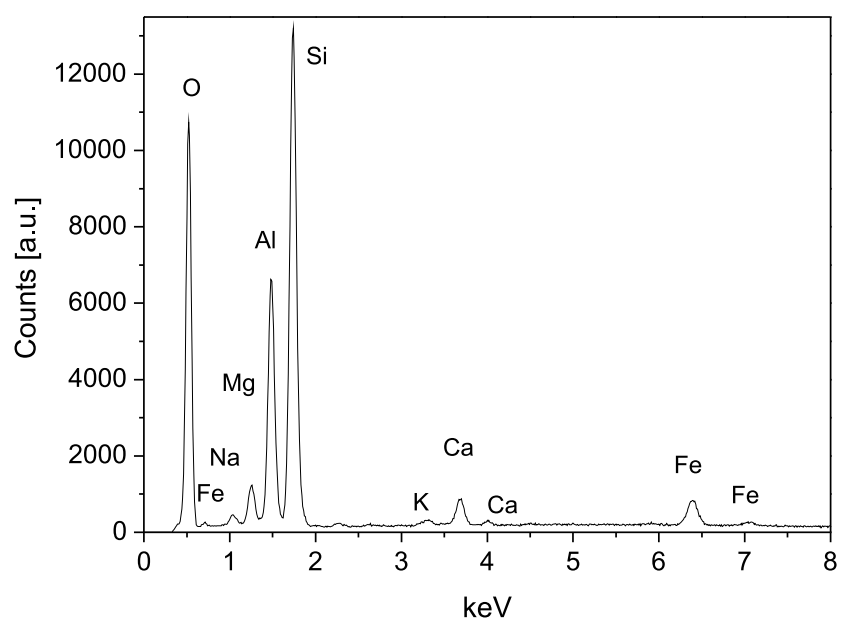

Figure 5. EDX spectra of catalyst

The elemental composition of sample determined by EDX was presented in Table 1.

Table 1. Elemental composition of the MMT catalyst determined by EDX

\begin{tabular}{|l|c|c|}
\hline Element & Element & wt\% \\
\hline & {$[w t \%]$} & Error \\
\hline $\mathrm{O}$ & 56.00 & 0.27 \\
\hline $\mathrm{Na}$ & 0.69 & 0.04 \\
\hline $\mathrm{Mg}$ & 2.09 & 0.03 \\
\hline $\mathrm{Al}$ & 10.41 & 0.06 \\
\hline $\mathrm{Si}$ & 26.13 & 0.10 \\
\hline $\mathrm{Ca}$ & 1.45 & 0.02 \\
\hline $\mathrm{Fe}$ & 3.24 & 0.08 \\
\hline
\end{tabular}

The specific crystalline phases present in the samples were indicated by labelling the major peaks in Figure 6. Results of the XRD measurements indicated presence of montmorillonite and more specifically $\mathrm{Ca}_{0.2}(\mathrm{Al}$, $\mathrm{Mg})_{2} \mathrm{Si}_{4} \mathrm{O}_{10}(\mathrm{OH})_{2} \cdot 4 \mathrm{H}_{2} \mathrm{O}$ (JCPDS: 13-0135) as the main phase. No phase containing $\mathrm{Fe}$ and $\mathrm{Na}$ was observed. 
The peaks are not present in the XRD pattern if compound is amorphous or particles are too small to result in Bragg diffraction. The compound of Fe can not be identified because the main peaks of Fe compound are similar to peaks of montmorillonite like in magnetite (JCPDS: 89-0951).

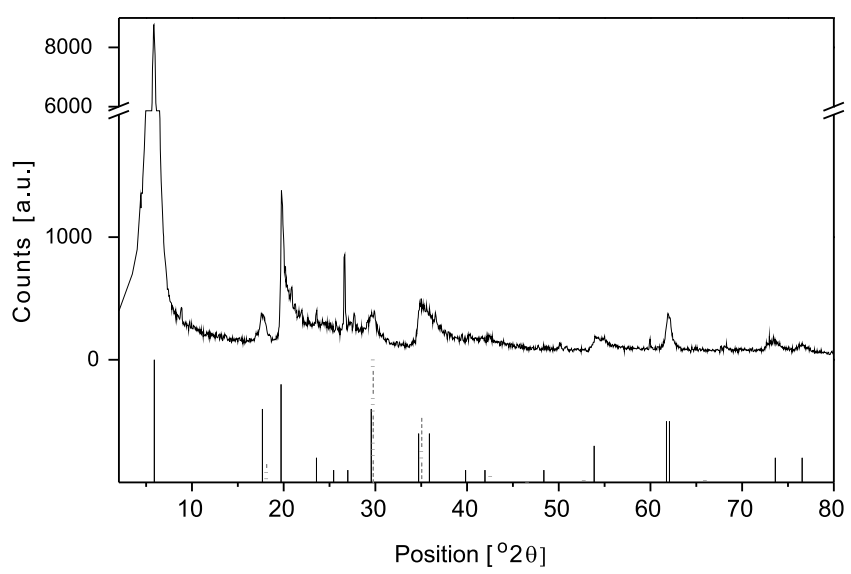

Figure 6. XRD diffractions of catalyst. Pattern of montmorillonite $\mathrm{Ca}_{02}(\mathrm{Al}, \mathrm{Mg})_{2} \mathrm{Si}_{4} \mathrm{O}_{10}(\mathrm{OH})_{2} \cdot 4 \mathrm{H}_{2} \mathrm{O}$ according to JCPDS: $13-0135$ |, pattern of magnetite $\mathrm{Fe}_{2} \mathrm{O}_{3}$ according to JCPDS: 89-0951

The $\mathrm{N}_{2}$-sorption isotherm of MMT is presented in Figure 7.

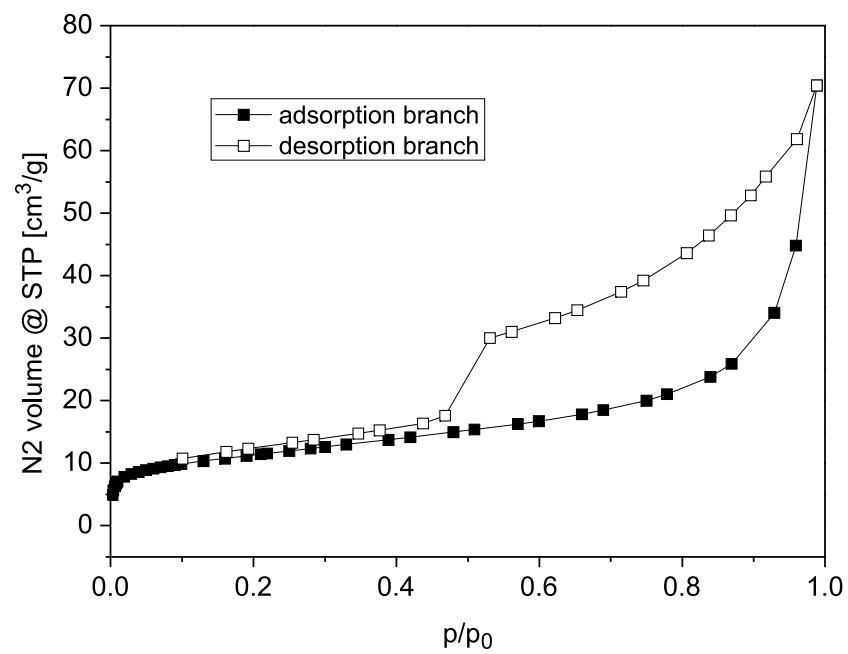

Figure 7. Nitrogen adsorption-desorption isotherms for catalyst

The $\mathrm{N}_{2}$-sorption isotherm shows a type IV isotherm with $\mathrm{H}_{2}$ hysteresis loop at relative pressure range, $\mathrm{p} / \mathrm{p}_{0}$ 0.4-1. Based on the shape of $\mathrm{N}_{2}$ adsorption isotherm mesoporous nature of catalyst can be assumed. A sharp fall of the desorption branch at $\mathrm{p} / \mathrm{p}_{0} 0.47-0.53$ was observed that are because to the sudden emptying of $\mathrm{N}_{2}$ from the internal layers of sorbent structure. The BET surface area of catalyst was found to be $39 \mathrm{~m}^{2} / \mathrm{g}$ with a pore volume of $0.109 \mathrm{~cm}^{3} / \mathrm{g}$. There were no micropores. The main pore diameter was about $5.5 \mathrm{~nm}$ (Fig. 8).

The SEM image of the catalyst (Fig. 9) showed a face-to-edge contact between the flake-shaped particles with a random orientation. No formation of domains (group of particles that act as a unit) or clusters (group of domains that act as a unit) was observed.

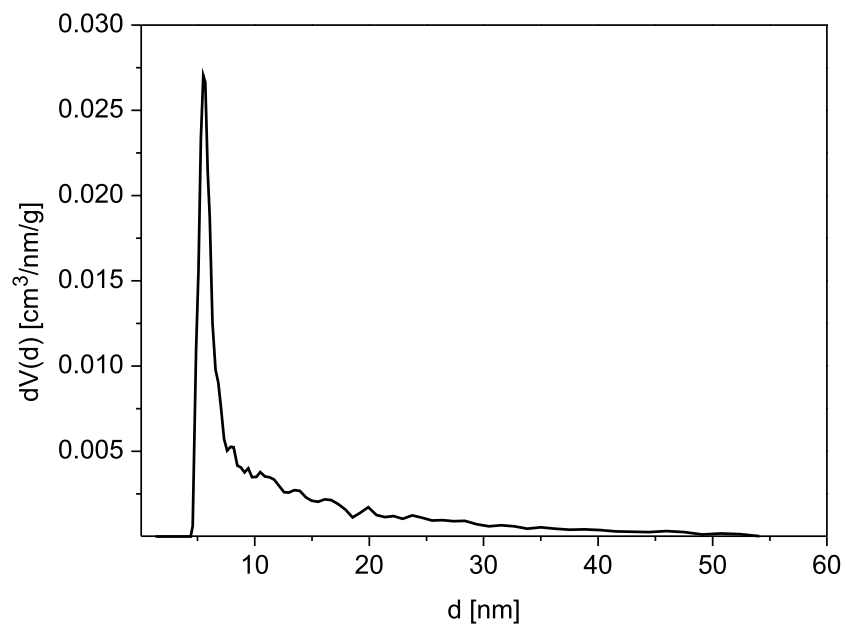

Figure 8. Pore size distribution for the catalyst
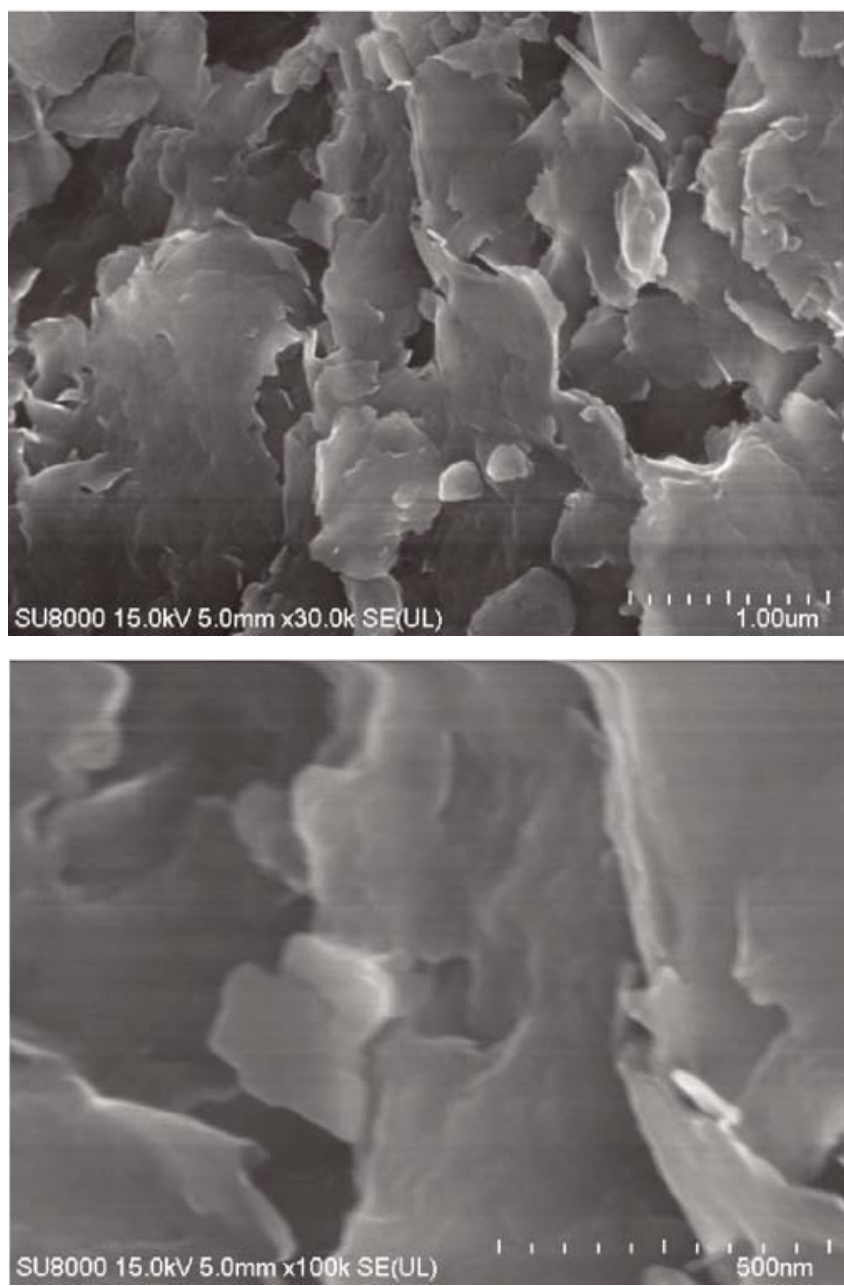

Figure 9. SEM images of MMT catalyst

\section{Oxidation of R-(+)-limonene}

Figure 10 shows reactions of $\mathrm{R}-(+)$-limonene which proceeded during the oxidation with hydrogen peroxide over sodium montmorillonite. In our oxidation process, the highest conversion of $\mathrm{R}-(+)$-limonene was obtained at the temperature of $100^{\circ} \mathrm{C}$ and it amounted to about $90 \%$ mol after $24-48 \mathrm{~h}$ of reaction performing (Fig. 11). At all studied temperatures the conversion of hydrogen peroxide reached almost $100 \mathrm{~mol} \%$ (Fig. 12). At all studied temperatures the main product of $\mathrm{R}-(+)$-limonene oxidation was $(1,2-8,9)$-diepoxide of $\mathrm{R}-(+)$-limonene. The selectivity of this diepoxide product at the temperature of $40^{\circ} \mathrm{C}$ changed from $48-45 \%$ 


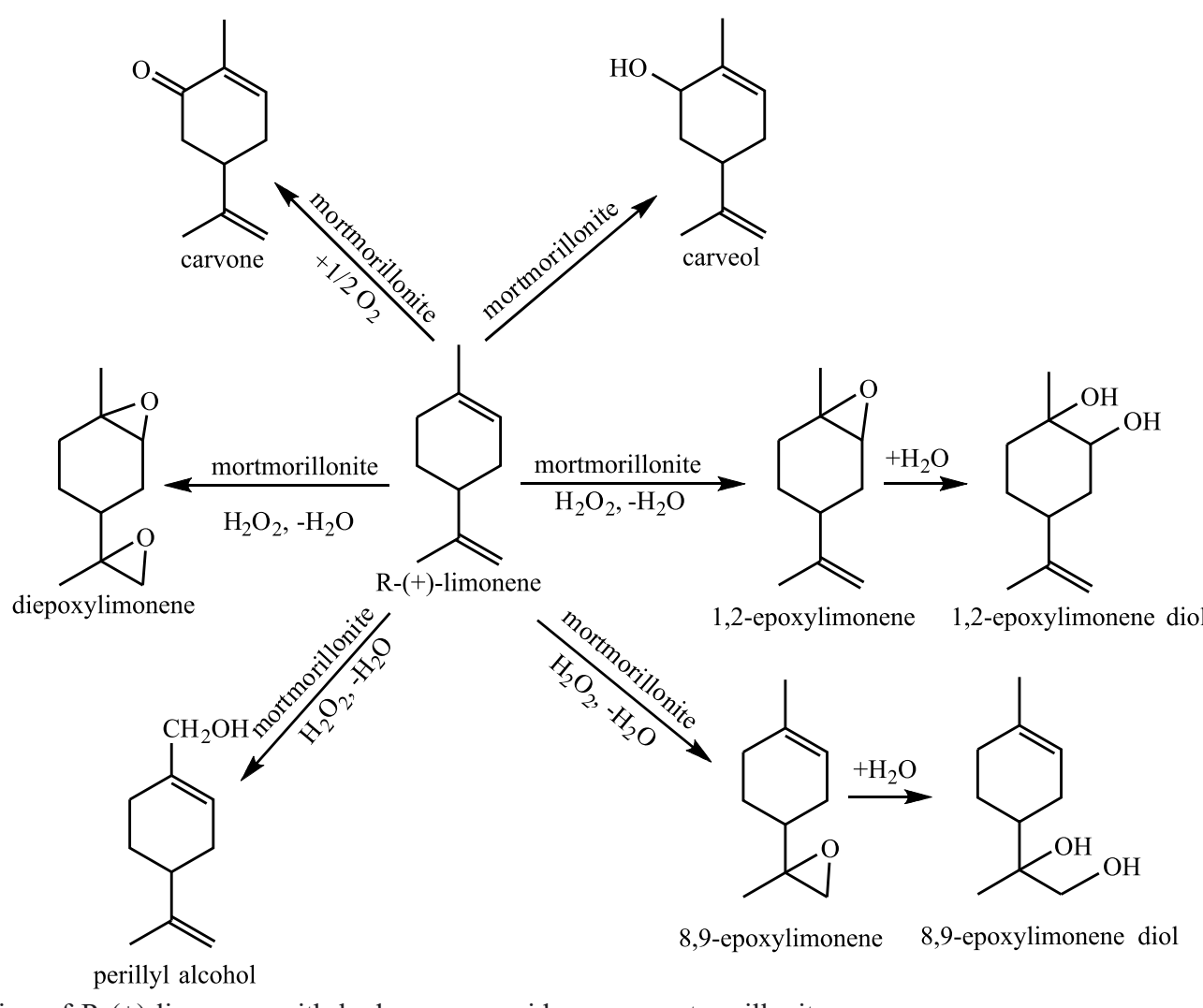

Figure 10. Oxidation of R-(+)-limonene with hydrogen peroxide over montmorillonite

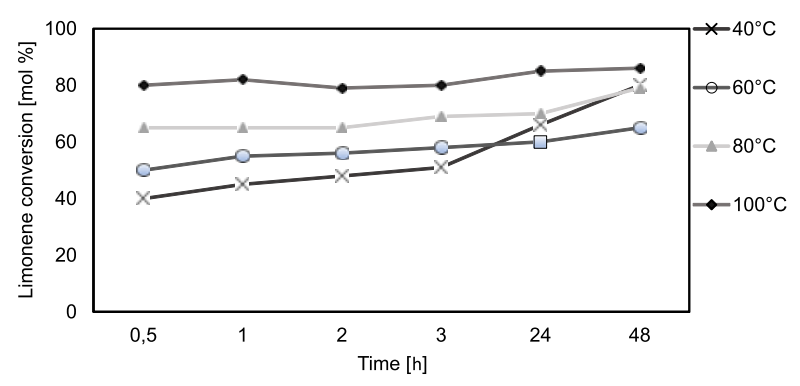

Figure 11. Limonene conversion during the process of limonene oxidation with hydrogen peroxide over montmorillonite)

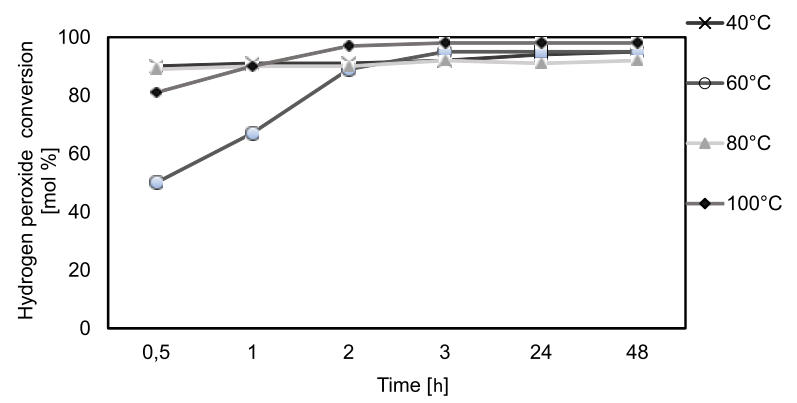

Figure 12. Hydrogen peroxide conversion during the process of limonene oxidation over montmorillonite

mol (reaction time 0.5 and $1 \mathrm{~h}$ ) to $30 \%$ mol (reaction time $48 \mathrm{~h}$ ) - Figure 13. For the temperature of $60^{\circ} \mathrm{C}$ the selectivity of $(1,2-8,9)$-diepoxide of R- $(+)$-limonene changed from $45 \mathrm{~mol} \%$ to $20 \% \mathrm{~mol}$ for the same range of the reaction time - Figure 14. For the temperature of $80^{\circ} \mathrm{C}$ the selectivity of this diepoxide compound was high in the whole range of studies reaction time and it raised from $50 \mathrm{~mol} \%$ (reaction time $0.5 \mathrm{~h}$ ) to $69 \mathrm{~mol} \%$ (reaction time $48 \mathrm{~h}$ ) - Figure 15. At the temperature of $100^{\circ} \mathrm{C}$ the selectivity of $(1,2-8,9)$-diepoxide of $\mathrm{R}-(+)$ -

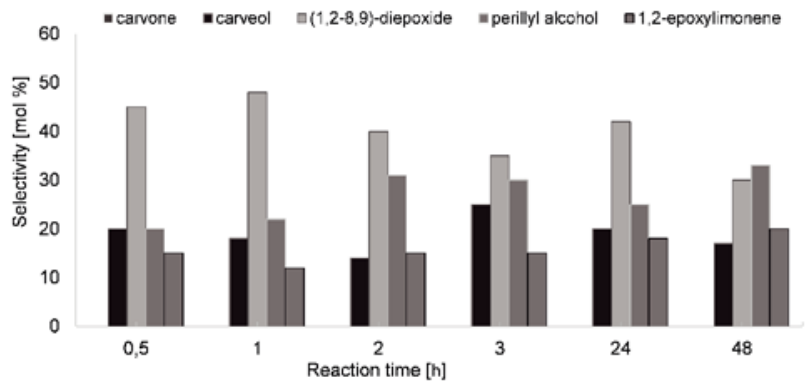

Figure 13. Influence of reaction time for selectivity of R-(+)-limonene products at $40^{\circ} \mathrm{C}$

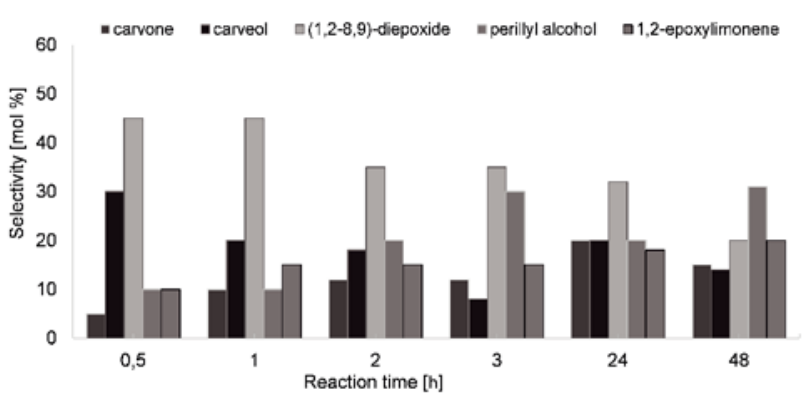

Figure 14. Influence of reaction time for selectivity of R-(+)-limonene products at $60^{\circ} \mathrm{C}$

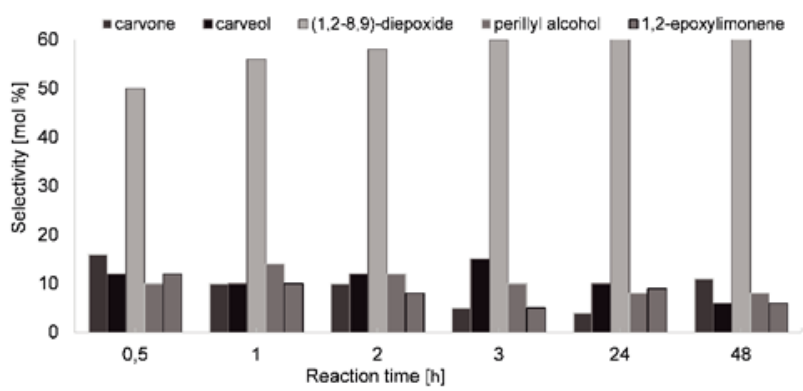

Figure 15. Influence of reaction time for selectivity of R-(+)-limonene products at $80^{\circ} \mathrm{C}$ 
-limonene was the highest from the studied temperatures and raised slightly from $74 \mathrm{~mol} \%$ (reaction time $0.5 \mathrm{~h}$ ) to $79 \mathrm{~mol} \%$ (reaction time $48 \mathrm{~h}$ ) - Fig. 16.

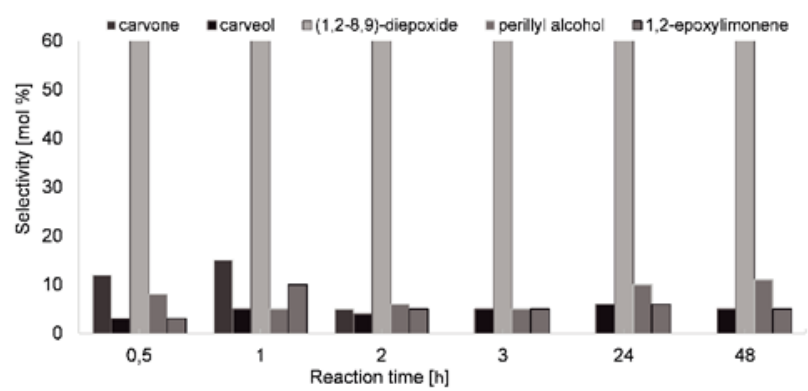

Figure 16. Influence of reaction time for selectivity of R-(+)-limonene products at $100^{\circ} \mathrm{C}$

At the temperature of $40^{\circ} \mathrm{C}$ formation of carvone was not observed, at higher temperatures this compound was detected in the post-reaction mixtures and its selectivity amounted to about $10-20 \mathrm{~mol} \%$ (temperature $60^{\circ} \mathrm{C}$ ), 4-16 mol\% (temperature $80^{\circ} \mathrm{C}$ ) and 5-12 mol\% (temperature $100^{\circ} \mathrm{C}$ ), but for the reaction time of $3-48 \mathrm{~h}$ at the temperature of $100^{\circ} \mathrm{C}$ this compound selectivity amounted to $0 \mathrm{~mol} \%$.

The next by-product which was detected in the post-reaction mixtures was carveol. Its selectivity amounted to about $14-25 \mathrm{~mol} \%$ (temperature $40^{\circ} \mathrm{C}$ ), $8-30 \mathrm{~mol} \%$ (temperature $60^{\circ} \mathrm{C}$ ), 6-15 mol\% (temperature $80^{\circ} \mathrm{C}$ ) and 3-6 mol\% (temperature $100^{\circ} \mathrm{C}$ ). formed with lower selectivities. The lowest selectivities were observed for carvone.

\section{Isomerization of R-(+)-limonene}

Figure 17 shows reactions of $\mathrm{R}-(+)$-limonene which proceeded during isomerization of $\mathrm{R}-(+)$-limonene over sodium montmorillonite as catalyst. This scheme illustrates the complexity of the limonene isomerization mechanism. In our isomerization studies the main product was p-cymene. The selectivities of products of isomerization of R-(+)-limonene are shows in Figure 18. The selectivity of p-cymene at temperatures of $140-180^{\circ} \mathrm{C}$ was about $50 \mathrm{~mol} \%$. At lower temperatures, R- $(+)$-limonene is isomerized with higher selectivity to terpinolene (with the selectivity of about $30 \mathrm{~mol} \%$ ), this may mean that the reaction temperature is a major determinant of the reaction rate. Reaction temperatures above $180^{\circ} \mathrm{C}$ after 6 hours lead to significant amounts of polymeric products resulting in lowered selectivity for valuable monoterpenes.

The R-(+)-limonene conversion (Fig. 19) increased with temperature, reaching the maximum value (100 mol\%) at the temperature of $160^{\circ} \mathrm{C}$ after $6 \mathrm{~h}$. At temperatures above $160^{\circ} \mathrm{C}$ after 6 hours, significant amounts of byproducts having higher molecular weights were formed (with the selectivity of about $40 \mathrm{~mol} \%$ ). Further studies should investigate the progress of the reaction at lower temperatures, thereby reducing the number of polymeric products.

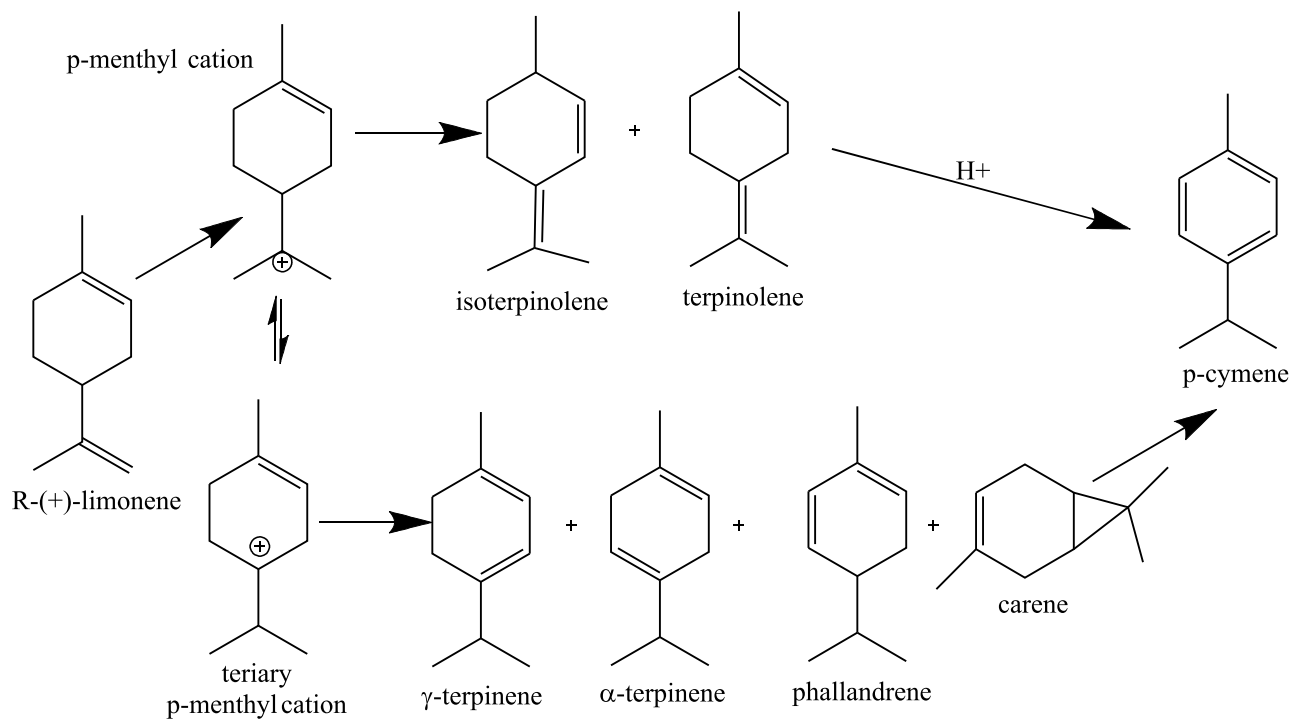

Figure 17. Products of isomerization of R-(+)-limonene over montmorillonite catalyst

1,2-epoxylimonene was also the by-product of R-(+)-limonene oxidation. Its selectivity amounted to about $12-20 \mathrm{~mol} \%$ (temperature $40^{\circ} \mathrm{C}$ ), $10-20 \mathrm{~mol} \%$ (temperature $60^{\circ} \mathrm{C}$ ), 5-12 $\mathrm{mol} \%$ (temperature $80^{\circ} \mathrm{C}$ ) and 3-10 mol\% (temperature $100^{\circ} \mathrm{C}$ ).

Also formation very valuable product - perillyl alcohol was observed during our studies. Its selectivity amounted to about $20-33 \mathrm{~mol} \%$ (temperature $40^{\circ} \mathrm{C}$ ), $10-31 \mathrm{~mol} \%$ (temperature $60^{\circ} \mathrm{C}$ ), $8-14 \mathrm{~mol} \%$ (temperature $80^{\circ} \mathrm{C}$ ) and 5-11 mol\% (temperature $100^{\circ} \mathrm{C}$ ).

Generally, the main product during our studies on oxidation of R-(+)-limonene over MMT was (1,2-8,9)-diepoxide. During by-products the main by-product was perillyl alcohol. Carveol and 1,2-epoxylimonene were

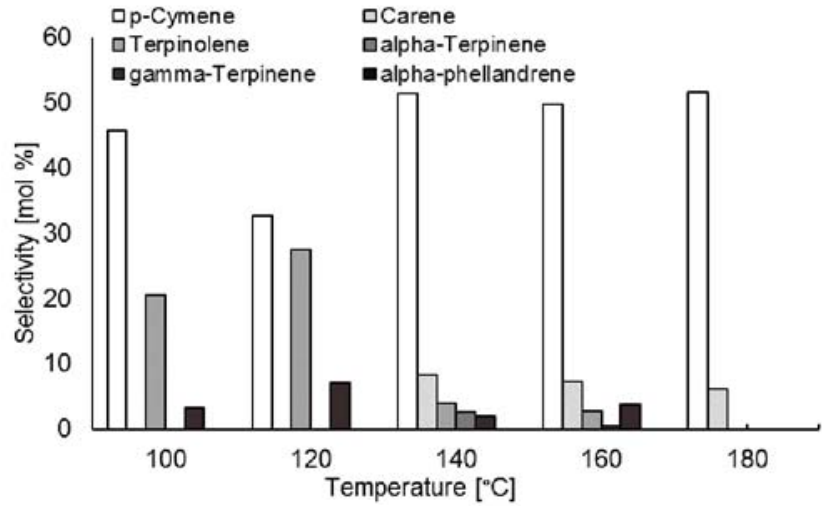

Figure 18. Selectivity of products obtained during R-(+)-limonene isomerization over montmorillonite 


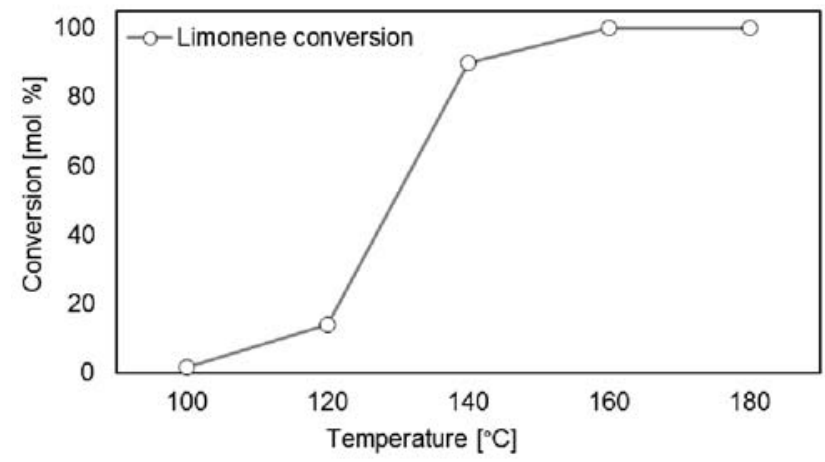

Figure 19. Conversion of $\mathrm{R}-(+)-$ limonene in isomerization process with montmorillonite

\section{CONCLUSIONS}

Montmorillonite was very active catalyst in processes of oxidation of R-(+)-limonene with $\mathrm{H}_{2} \mathrm{O}_{2}$ and in the process of isomerization of $\mathrm{R}-(+)$-limonene. In our studies, were obtained very important compounds as the main products $((1,2-8,9)$-diepoxide of limonene in the process of oxidation and p-cymene in the process of isomerization) which have many applications in cosmetic and pharmaceutical industry. Also by-products of both processes have many valuable applications.

The presented studies are only preliminary studies which should be continued. Both presented processes used renewable raw material - limonene and catalyst of natural origin, thus both processes are environmentally friendly, low cost and thus have perspectives of developing and implementation in organic chemistry plants. The next step should be studies on the influence of appropriate parameters on the course of this process. Especially, increasing of the selectivity of $(1,2-8,9)$-diepoxide of limonene and perillyl alcohol will be beneficial.

\section{LITERATURE CITED}

1. Królikowski, W. \& Rosłaniec, Z. (2004). Polymer nanocomposites. Kompozyty 4, 3-15 (in Polish)

2. Wilpiszewska, K., Antosik, A.K. \& Spychaj, T. (2017). Novel hydrophilic carboxymethyl starch/montmorillonite nanocomposite Films. Carbohydr. Polym. 128, 82-89. DOI: 10.1016/j. carbpol.2015.04.023.

3. Olejnik, M. (2008). Polymer nanocomposites involving montmorillonite - preparation, evaluation methods, properties and application. Tech. Wyr. Włók. 67-74. (in Polish).

4. Kacperski, M. (2003). Polymer nanocomposites, Kompozyty 3, 225-231. (in Polish).

5. Kacperski, M. (2002). Polymer nanocomposites. Polimery. 47, 801-807. (in Polish)

6. Malesa, M. (2004). Nanofillers of polymer composites. Elastomery, 3, 12-17 (in Polish)

7. Sikora, M. (2006). Rheological modifiers essential parameter of cosmetic products. Przem. Kosmetyczny 11, 26-31. (in Polish)

8. Kunert, A. \& Zaborski, M. (2010). Construction, properties and applications of layered minerals. Przem. Chem. 1, 1510-1517. (in Polish)

9. Komadel, P. (2016). Acid activated clays: Materials in continuous demand. Appl. Clay Sci. 131, 84-99. DOI: 10.1016/j. clay.2016.05.001.

10. Fernandes, C., Catrinescu, C., Castilho, P., Russo, P.A., Carrott, M.R. \& Breen, C. (2007). Catalytic conversion of limonene over acid activated Serra de Dentro (SD) bento- nite. Appl. Catal. A: General. 318, 108-120. DOI: 10.1016/j. apcata.2006.10.048.

11. Koolia, F., Liu, Y., Alshahateet Solhe, F., Messali, M. \& Bergaya, F. (2009). Reaction of acid activated montmorillonites with hexadecyl trimethylammonium bromide solution. Appl. Clay Sci. 43, 357-363. DOI: 10.1016/j.clay.2008.10.006.

12. Nagendrappa, G. (2011). Organic synthesis using clay and clay-supported catalysts. Appl. Clay Sci. 53, 106-138. DOI: 10.1016/j.clay.2010.09.016.

13. Stekrova, M., Kumara, N., Aho, A., Sinev, I., Grünert, W., Dahl, J., Roine, J., Arzumanov, S.S., Mäki-Arvela, P. \& Yu. Murzin, D. (2014). Isomerization of $\alpha$-pinene oxide using Fe-supported catalysts: Selective synthesis of campholenic aldehyde. Appl. Catal. A: General. 470, 162-176. DOI: 10.1016/j. apcata.2013.10.044.

14. Comelli, N., Avila, M.C., Volzone, C. \& Ponzi, M. (2013). Hydration of $\alpha$-pinene catalyzed by acid clays. Cent. Eur. J. Chem. 11, 689-697. DOI: 10.2478/s11532-013-0217-4.

15. Ravasio, N., Zaccheria, F., Gervasini, A. \& Messi, C. (2008). A new, Fe based, heterogeneous Lewis acid: Selective isomerization of a-pinene oxide. Catal. Commun. 9, 1125-1127. DOI: 10.1016/j.catcom.2007.10.019.

16. Kumar, V. \& Agarwal, A.K. (2014). A review on catalytic terpene transformation over heterogenous catalyst, Inter. J. Curr. Res. Chem. Pharm. Sci. 1, 78-88.

17. Volcho, K. \& Salakhutdinov, N.F. (2008). Transformations of Terpenoids on Acidic Clays. Mini-Rev. Org. Chem. 5, 345-354. DOI: 10.2174/157019308786242151.

18. Yadav, M.Kr., Chudasama, C.D. \& Jasra, R.V. (2004). Isomerisation of $\alpha$-pinene using modified montmorillonite clays. J. Mol. Catal. A: Chemical, 216, 51-59. DOI: 10.1016/j. molcata.2004.02.004.

19. Yarovaya, O.I., Korchagina, D.V., Salakhutdinov, N.F. \& Tolstikov, G.A. (2012). Reaction of isocembreol and alcohols on clay. Chem. Nat. Comp. 48, 57-59. DOI: 00093130/12/4801-0056.

20. Akgu, M., Ozyagcı, B. \& Karabakan, A.l. (2013). Evaluation of $\mathrm{Fe}$ - and $\mathrm{Cr}$-containing clinoptilolite catalysts for the production of camphene from a-pinene. J. Ind. Enginee. Chem. 19, 240-249. DOI: 10.1016/j.jiec.2012.07.024.

21. Ilina, I.V., Suslov, E.V., Khomenko, T.M., Korchagina, D.V., Volcho, K.P., Salakhutdinov, N.F. (2009). Natural Montmorillonite Clay as Prebiotic Catalyst. Paleont. J. 43, 958-964. DOI: $10.1134 /$ S0031030109080139.

22. Il'ina, I.V., Volcho, K.P., Korchagina, D.V., Barkhash, V.A. \& Salakhutdinov, N.F. (2007). Transformations of (-)-Myrtenal Epoxide over Askanite-Bentonite Clay. Rus. J. Org. Chem. 43, 56-59. DOI: 10.1134/S1070428007010058.

23. Wróblewska, A., Makuch, E. \& Miądlicki, P. (2016). The studies on the limonene oxidation over the microporous TS-1 catalyst. Catal. Today, 268, 121-129. DOI: 10.1016/j. cattod.2015.11.008.

24. Marino, D., Gallegos, N.G., Bengoa, J.F., Alvarez, A.M., Cagnoli, M.V., Casuscelli, S.G., Herrero, E.R. \& Marchetti S.G. (2008). Ti-MCM-41 catalysts prepared by post-synthesis methods: Limonene epoxidation with $\mathrm{H}_{2} \mathrm{O}_{2}$. Catal. Today. 133-135, 632-638. DOI: 10.1016/j.cattod.2007.12.111.

25. Wróblewska, A. (2014). The epoxidation of limonene over the TS-1 and Ti-SBA-15 catalysts. Molecules. 19, 19907-19922. DOI: 10.3390/molecules191219907.

26. Pinto, L.D., Dupont, J., de Souza, R.F., BernardoGusmão, K. (2008). Catalytic asymmetric epoxidation of limonene using manganese Schiff-base complexes immobilized in ionic liquids. Catal. Comm. 9, 135-139. DOI: 10.1016/j. catcom.2007.05.025.

27. Bussi, J., López, A., Peña, F., Timbal, P., Paz, D., Lorenzo, D. \& Dellacasa, E. (2003). Liquid phase oxidation of limonene catalyzed by palladium supported on hydrotalcites. Appl. Catal. A: General 253, 177-189. DOI: 10.1016/S0926$-860 X(03) 00519-2$. 
28. Ali, B., Al-Wabel, N.A., Shams, S., Ahamad, A., Khan, S.A. \& Anwar, F. (2015). Essential oils used in aromatherapy: A systemic review. APJTB 5, 601-611. DOI: 10.1016/j. apjtb.2015.05.007.

29. Chen, T.C., Fonseca, C.O.D. \& Schönthal, A.H. (2015). Preclinical development and clinical use of perillyl alcohol for chemoprevention and cancer therapy. Am. J. Can. Res. 5, 1580-1593.

30. Li, C.D., Sablong, R.J. \& Koning Cor, E. (2016). Chemoselective Alternating copolymerization of limonene dioxide and carbon dioxide: a new highly functional aliphatic epoxy polycarbonate. Angew. Chem. 128, 11744-11748. DOI: 10.1002/anie.201604674.

31. Morinaga, H. \& Sakamoto, M. (2017). Synthesis of multi-functional epoxides derived from limonene oxide and its application to the network polymers. Tetrahedron Lett. 58, 2438-2440. DOI: 10.1016/j.tetlet.2017.05.021.

32. Linnekoski, J.A., Asikainen, M., Heikkinen, H., Kaila, R. K., Räsänen, J. \& Harlin A. (2014). Production of p-cymene from crude sulphate turpentine with commercial zeolite catalyst using a continuous fixed bed reactor. Org. Process Res. \& Dev. 18, 1468-1475. DOI. 10.1021/op500160f. 